\title{
MONITORING OF SHORT-LIVED SNOW COVERAGE BY RADAR AND OPTICAL DATA FROM SENTINEL-1 AND SENTINEL-2 SATELLITES
}

\author{
Temenuzhka Spasova, Roumen Nedkov
}

\begin{abstract}
Snow cover monitoring shows the great importance of this rainfall, the time-lines of the data from this event, and the spatial range and area of the observed object.

The main aim of the presented research is to trace the use of different satellite data and approaches to track the dynamics of the development of the short-lived snow coverage.

The subject of the study is short-lived snow coverage and its dynamics for 12 and 13 March 13, 2017 for Sofia city area, Bulgaria. The objects were analyzed and mapped according to ESA data, acquired by sensors Sentinel-1 SAR and Sentinel-2 MSI.

Results have been obtained for quantitative changes of wet snow cover and its dynamics. The data used are with a high time-spatial resolution, which is imperative when it is need to study a short-lived event such as the wet snow coverage.

The importance of this monitoring is that the remote sensing and reliable data required calculating models of climate, natural disasters and crashes have been obtained.
\end{abstract}

Keywords: snow cover, radar satellite data, microwave range, optical range, Sentinel-1 SAR, Sentinel-2 MSI.

\section{INTRODUCTION}

The subject of the study is the short-lived snow coverage or so-called wet snow and its dynamics for Sofia city area, registered on 12 and 13 March, 2017. The objects were analyzed and mapped according to European Space Agency data (ESA data), acquired by sensors Sentinel-1 SAR and Sentinel-2 MSI [4].

The main purpose of this study is to track the use of different satellite data and approaches to study the dynamics of wet snow cover.

The snow is the component of the cryosphere with the largest seasonal variation in spatial extent. In fact accumulation and rapid melt of snow are two of the most dynamical seasonal environmental changes on the Earth's surface. [2]

The large scale changes in snow cover are useful as indicators of climatic variations, snow also affects other components of the Earth system at a variety of scales. By virtue of its radiative and thermal properties, snow affects the overlying atmosphere and thereby plays an important role in the complex web of feedbacks that control local to global climate. For example, because of the high albedo of snow, its presence can change the surface energy balance over land and therefore affect climate (i.e. the snow-albedo feedback). Snow also modulates the hydrologic cycle, influences ecosystem functioning and is a significant resource for many mid-latitude populations and for populations whose water is derived from mountainous and northern cold areas. Snow observations are critical for the validation of climate models. [2]
Because of the large extent of terrestrial snow cover and the difficulties in obtaining ground measurements over cold regions, remote sensing represents an important tool for studying snow properties at regional to global scales [2].

\section{DATA AND METHODS}

\section{Data used}

Due to the nature of interactions between snow cover and electromagnetic radiation of different frequencies, snow can be distinguished from other terrestrial surfaces using satellite observations based on a number of different active and passive techniques [1]. The two types of instruments used for monitoring global scale snow variations rely on either (1) a combination of the visible and infrared, or (2) microwave, portions of the electromagnetic spectrum. These methods are limited by a number of factors, such as clouds, forest cover fraction, terrain heterogeneity and precipitation. For example, interpretation of visible and infrared images can be difficult where complex terrain causes considerable spatial variation within each remotely-sensed footprint of snow depth, surface characteristics, and satellite viewing angles. However, most of the products are based on these observations [2]. Similarly, the ESA Sentinel-2-MSI product, which is a passive optical sensor, is used in this study.

The Sentinel-1SAR- images (Synthetic Aperture Radar images) has the ability to provide both day-time and night-time imagery. Despite all the difficulties such as fog, snow, light rain, smoke or clouds, for a wet moderate climate SAR image is the most appropriate instrument for flood 
monitoring and short-lived snow coverage (wet snow). Sentinel-1 SAR has the ability to detect open water surfaces, shallow sub-surface water, moisture, changes in soil moisture, wet snow, and the ability to distinguish between wet snow and dry snow [3]. Using SAR images can to track the dynamics of snow melting [8].

\section{Image processing methods}

Fig. 1 shows a composite optical image of Sentinel-2 MSI of March 28, 2017, showing the presence of snow through bands 12, 11, 4 [5]. For verification, five test areas are selected on the optical image whose spectral characteristic indicates that it is snow on Fig. 2.

Fig. 3a and Fig. 3b show a composite optical and composite radar image. In the radar image are included: $12 / 03 / 17$ - date before the date of the event and $13 / 03 / 17$ - the date of the event. Here the event date from the radar image is placed in the B (Blue)band of the RGB model. This way the places with wet snow or moisture stand out, which are again in a dark blue or purple pseudo color [6]. The five selected test areas are also applied to the radar image and could be used to validate the data for the location of the wet snow cover.

In order to track the dynamics of such event as wet snow, it is necessary to use images with a higher temporal resolution and for this purpose six dates of Fig. 5 are used within two weeks. The period is covering the time before and after the event [8]. A composite image based on a different type of polarization ( $\mathrm{hv}$ - horizontal-vertical and $\mathrm{vv}$ vertical) is generated. The following combination is used: R - vh, G - vv, B - vh / vv. The aim is to visualize the area of the wet snow cover. The wetlands and water bodies are clearly visible [10]. On Fig. 5d, dated March 13, 2017, the wet snow contrasts against the background of the others. The wet snow in radar images is characterized by a high reflectance, and due to the surface roughness, a higher value signal can be recorded that reaches the sensor.

The three-date composite radar images on Fig. 6a and Fig. 6b with both types of hv- and vv polarization show very small differences in the wet snow registered values. In both cases places with snow presence are clearly visible, as long as the date with the event is placed in the B-band of the RGB model. When plotting the area reflectance the values reach over 700-800 in both types of polarization (see Fig. 7a and Fig.b). This indicates the presence of wet snow, as it is characterized by much higher reflectance than those of the water.
Similar is the situation with composite images in the same order of dates but transformed into dB (decibels) - see Fig. 8a and Fig. 8b. Here the minimum difference is very important because hvpolarization gives higher values. This is due to the terrain orography and the way the signal returns to the sensor. It can be assumed that values between 25 and $28 \mathrm{~dB}$ are a reliable indicator for wet snow. For the spatial reflectance distribution of wet snow on Fig. 9a and Fig. 9 b (in dB) for the same place from $13 / 03 / 17$, very clearly the higher values in hvpolarization in certain places are seen, the same is valid for even the lowest values, and for those absent in other places.

\section{RESULTS AND DISCUSSION}

Data from Sentinel-2 MSI can be used to locate the presence or absence of wet snow. Optical images have a lower temporal resolution, making them less suitable for urban monitoring, as wet snow melts faster. Channels used to detect snow cover are as in MODIS [8]

Composite radar images of two dates use pseudo-colors that help to recognize wet snow and water easier. The wet snow, moisture and water are recognized in the used radar image of 13.03.17 (from the day of the event) in to the B-band from the RGB model. For short-lived snow, such as wet snow is, the dynamic of its preservation can be easily tracked. The changes that occur in the landscape within two or three days and the great contrasts within just one week can be perfectly tracked in an accurate manner.

Composites of three dates with hv- and vvpolarization show good spatial distribution of wet snow. On the graphs of Fig.7, dated 13/03/17, it proves through its high reflectance that there is a wet snow cover. The high resolution of the radar images and the results obtained are the grounds to conclude that this is short-lived snow coverage.

The $\mathrm{dB}$ three-day composite images show that values above $25 \mathrm{~dB}$ to $28 \mathrm{~dB}$ are a correct indicator for wet snow. Values below $25 \mathrm{~dB}$ can be taken as water. A much better evaluation can be done through $\mathrm{vv-}$ polarization. Here, the differences in both polarizations are in the 1-2 $\mathrm{dB}$ range. Due to this, the different types of wet snow and water can be discriminated. The days, before the event $-12 / 03 / 17$ and after the event - 18/03/2017, when the values for the presence of wet snow are much lower, are clearly visible. It can be accepted that the data from vv-polarization are more representative and give more accurate information. 


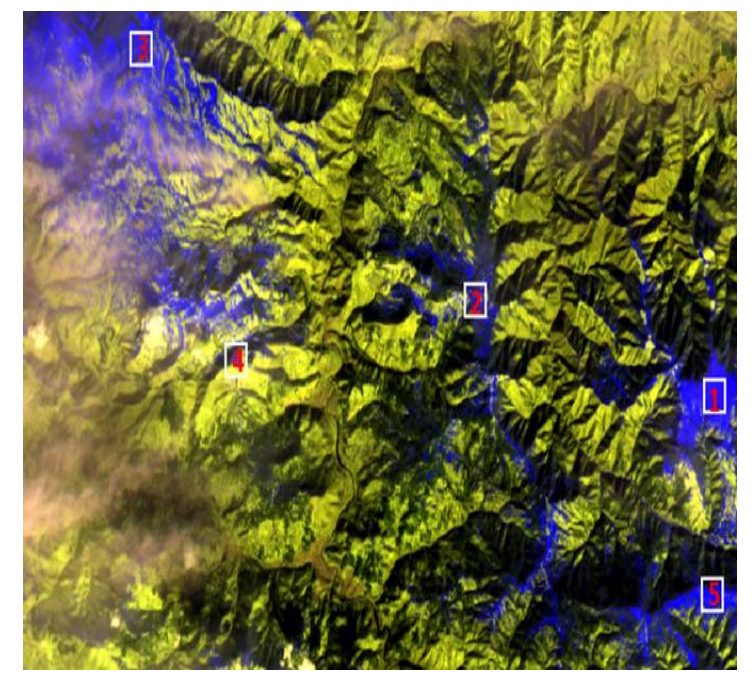

Fig. 1. Composite image from Sentinel -2 with the test areas - bands 12, 11, 4

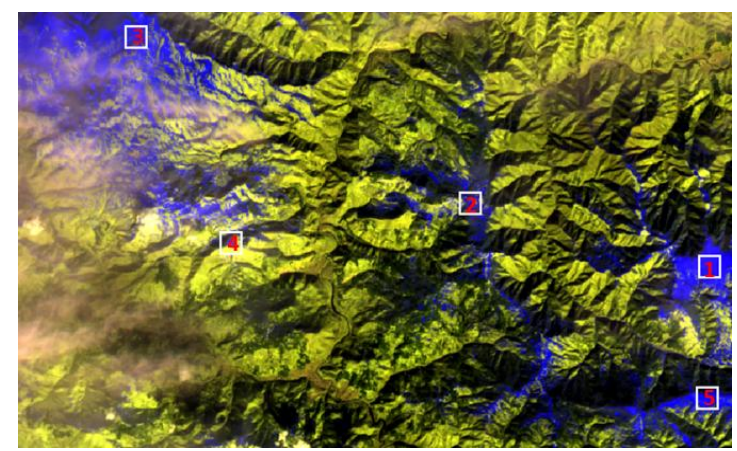

Fig3a. Composite image from Sentinel -2 with the test areas - bands 12, 11, 4

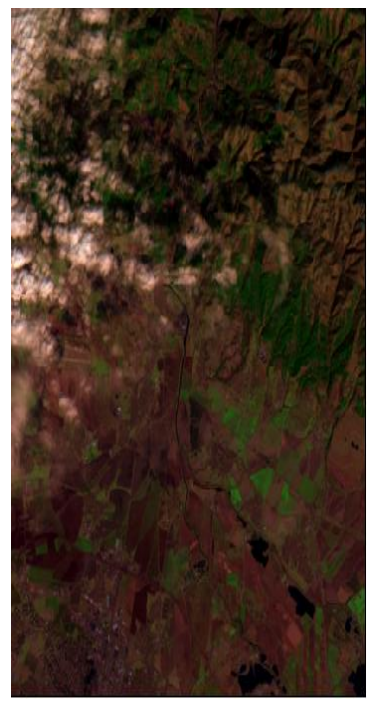

Fig. 4 a) Composite imageSentinel 2- bands $12,8 \mathrm{a}, 4-28 / 02 / 17$

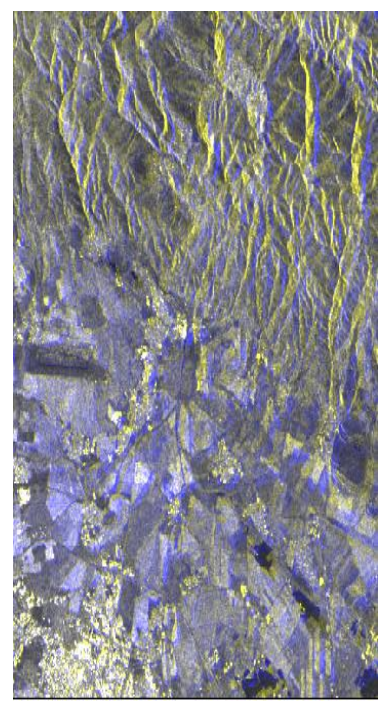

b) Composite SAR image $\mathrm{VV}$ poliarization

R-12/03/17, G -12/03/17, B- $13 / 03 / 17$

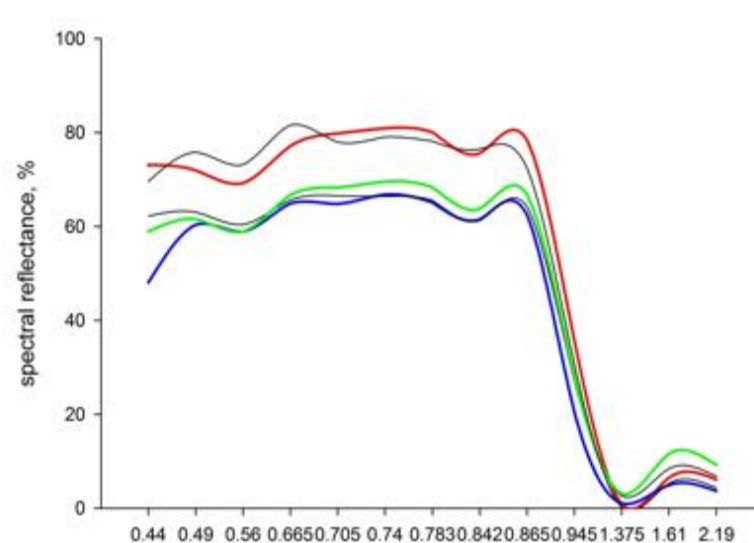

$$
\text { wavelength, } \mu \mathrm{m}
$$

- spectral reflectance, $\%(1)$

- spectral reflectance, $\%(2)$

- spectral reflactance $\%(4)$

Fig. 2. Spectral characteristic of snow for the test areas

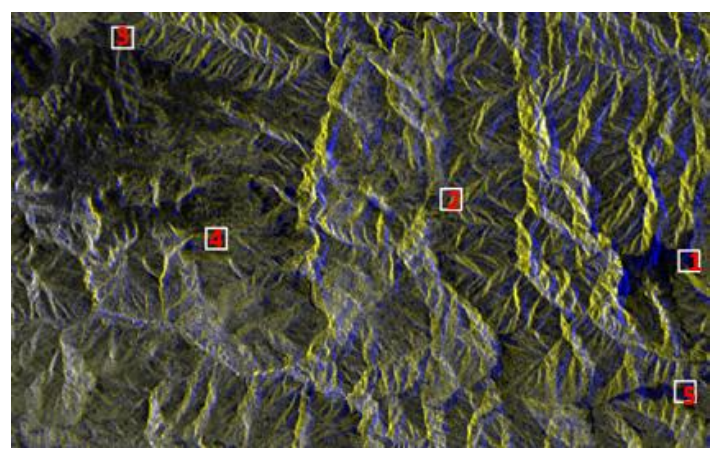

Fig. 3b. Composite SAR image with the test areas $\mathrm{R}$ - vv 18/03/17,G - vv 18/03/17,B - vv13/03/17
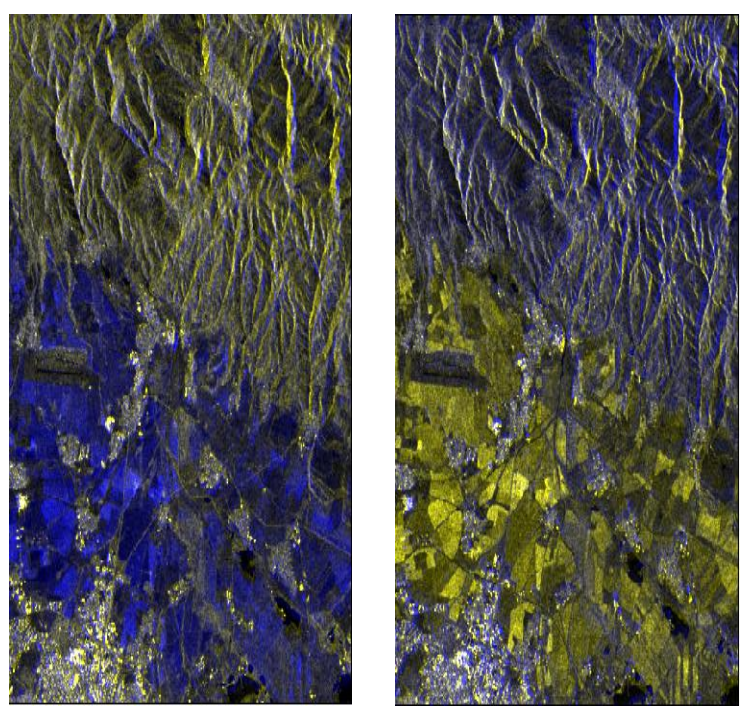

c) Composite SAR image d) Composite SAR image VV poliarization VV poliarization-

R-18/03/17, G - 18/03/17, R-13/03/17, G - 13/03/17,
B- $13 / 03 / 17$
B- $18 / 03 / 17$ 


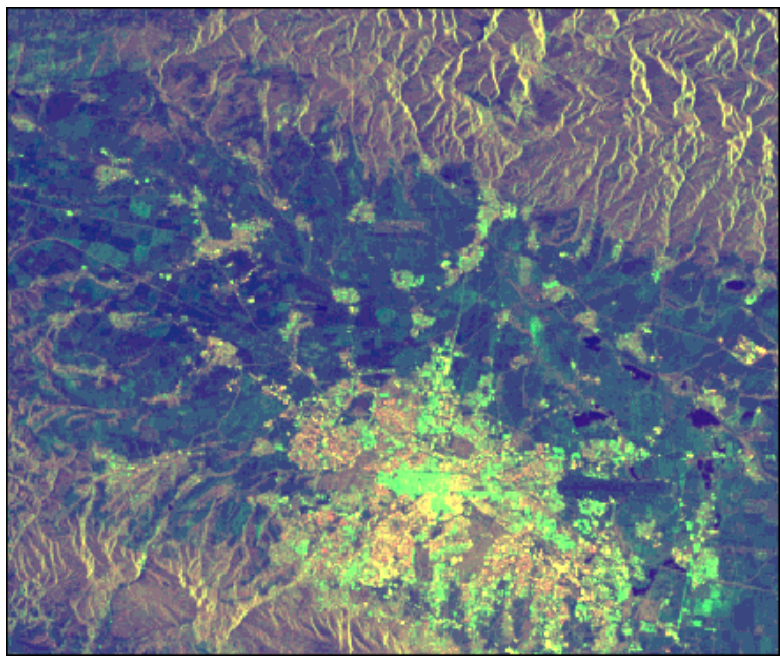

a) 05/03/17 R- vh, G- vv, B-vh/vv

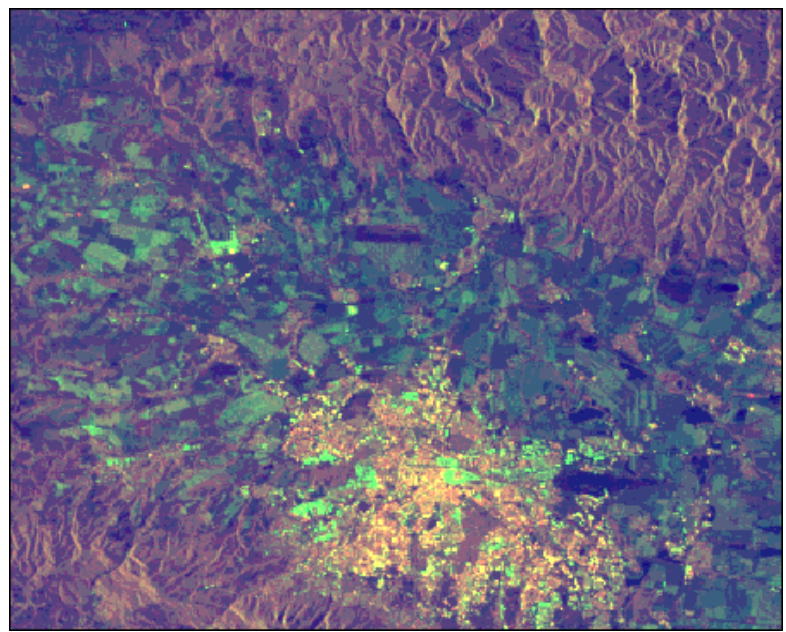

c) $12 / 03 / 17$ R- vh, G- vv, B-vh/vv

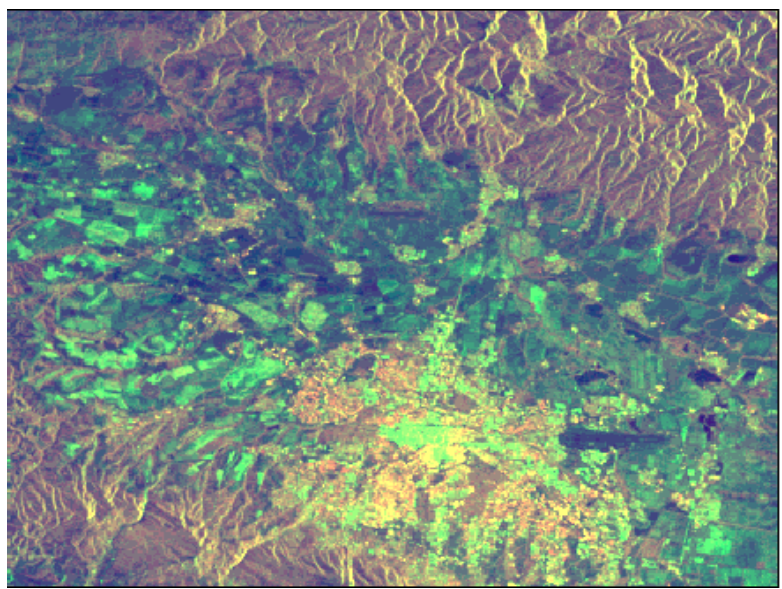

e) $17 / 03 / 17$ R- vh, G- vv, B-vh/vv

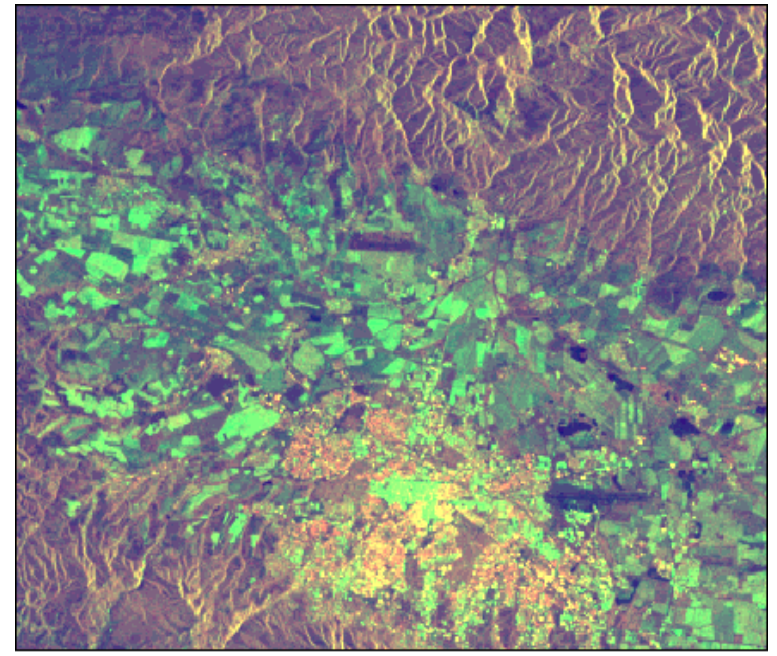

b) $11 / 03 / 17$ R- vh, G- vv, B-vh/vv

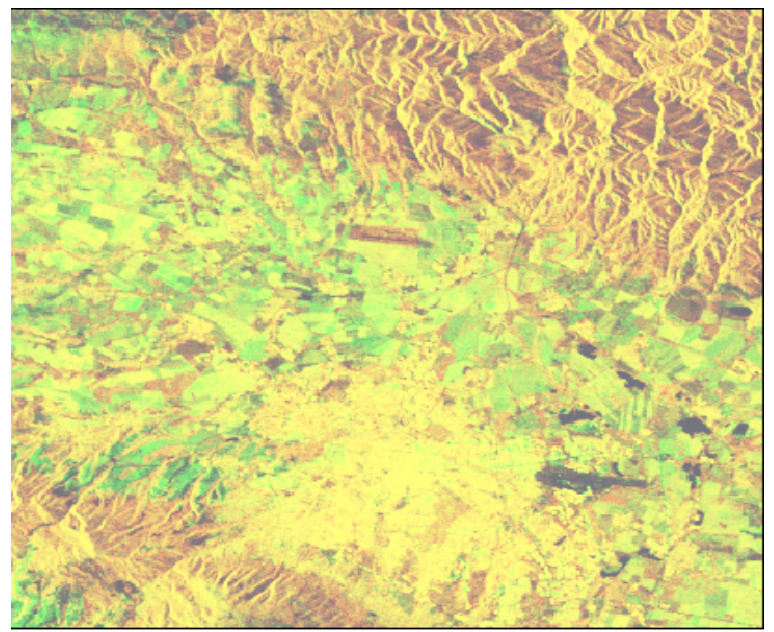

d) $13 / 03 / 17$ R- vh, G- vv, B-vh/vv

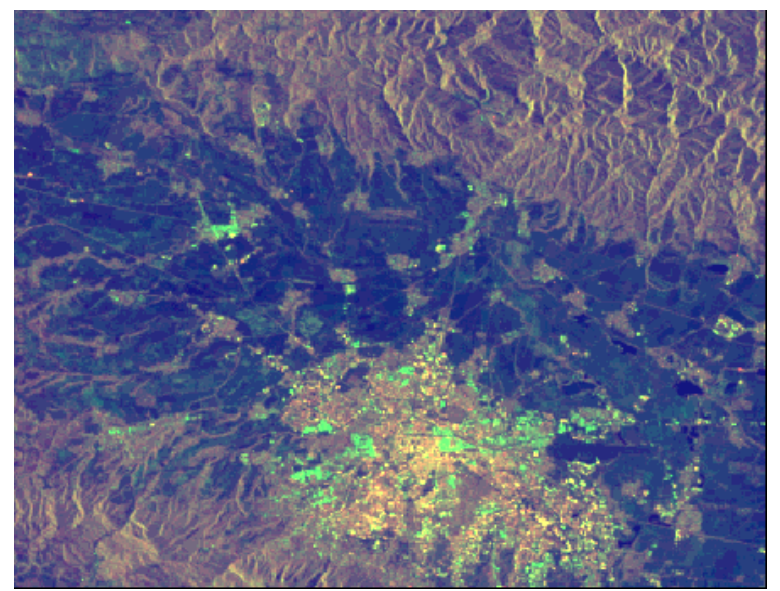

f) $18 / 03 / 17$ R- vh, G- vv, B-vh/vv

Fig. 5. Composite SAR images with different polarization 


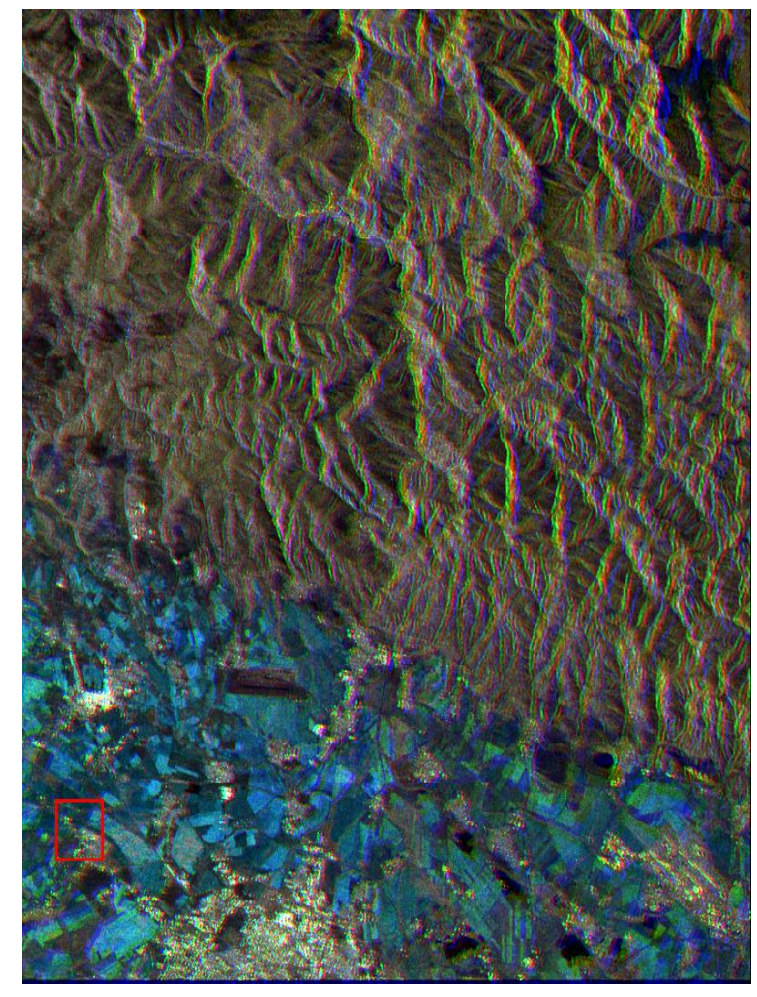

a) vv poliarization R-18/03/17, G-12/03/17, B-13/03/17

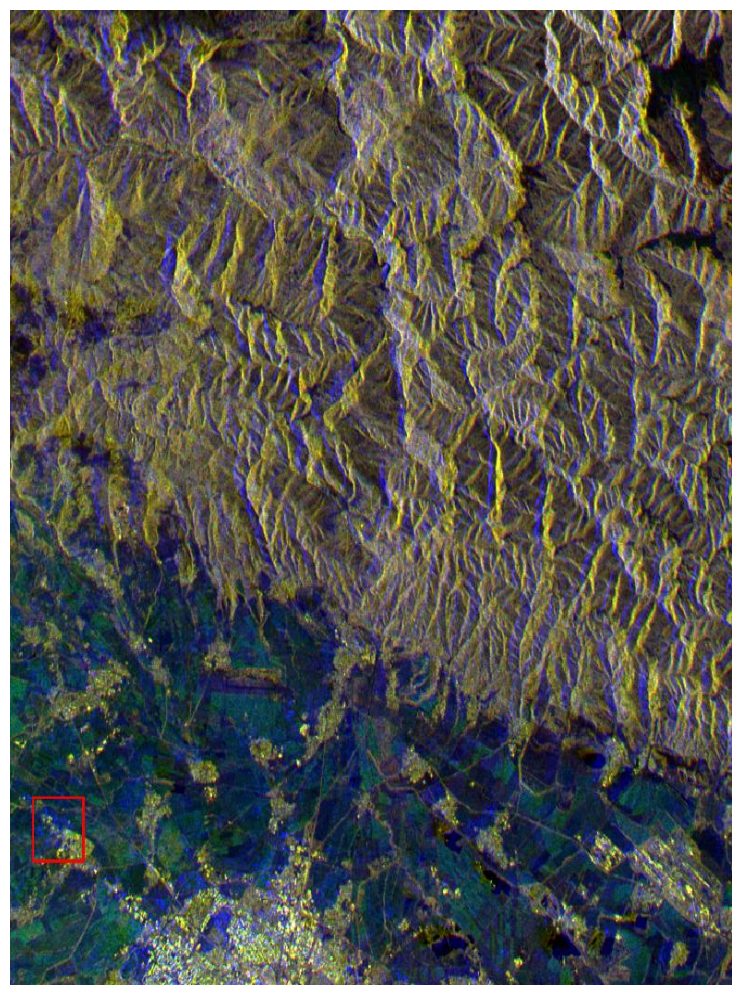

b) vh poliarization R-18/03/17, G-12/03/17, B-13/03/17

Fig. 6. Composite SAR images

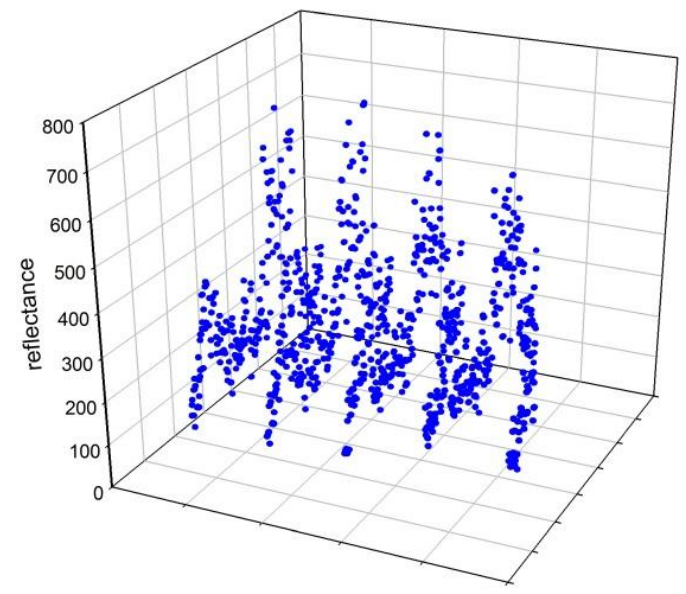

a) vv poliarization $-13 / 03 / 17$

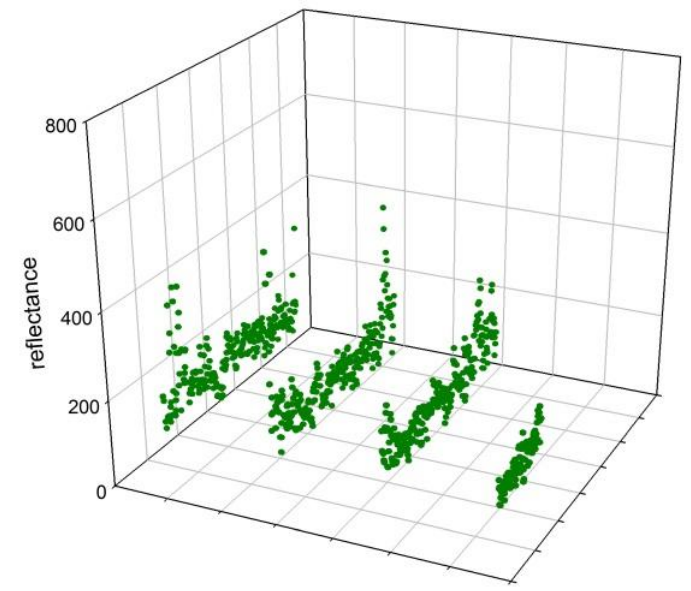

b) vh poliarization - $13 / 03 / 17$

Fig. 7. Spatial reflectance distribution of wet snow 


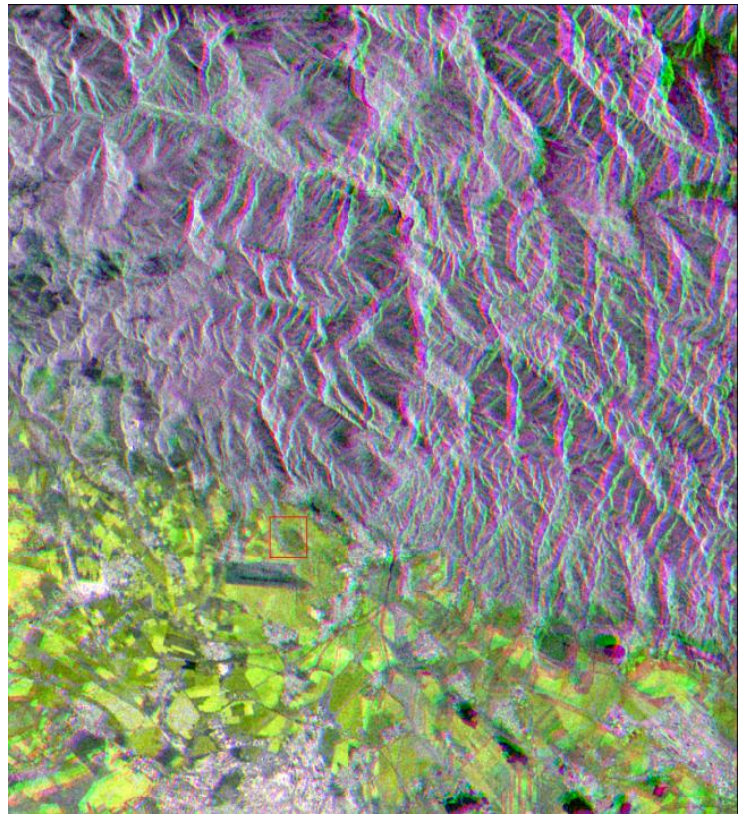

a) VV poliarization with three different dates: R-12/03/17, G- 13/03/17, B- 18/03/17 (dB)

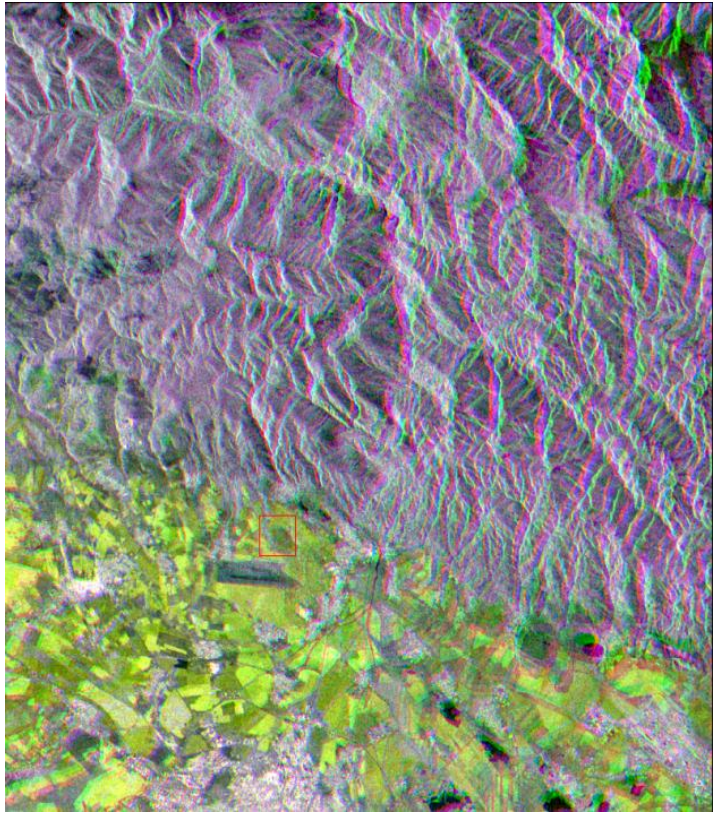

b) $\mathrm{VH}$ poliarization with three different dates: R-12/03/17, G-13/03/17, B-18/03/17 (dB)

Fig. 8. Composite SAR images in $\mathrm{dB}$

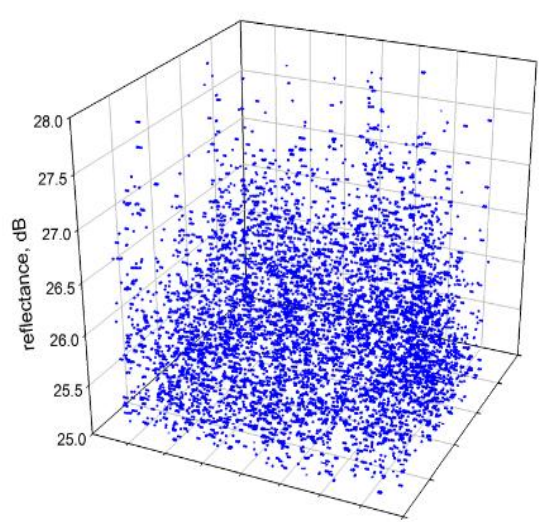

a) VV poliarization $-13 / 03 / 17$

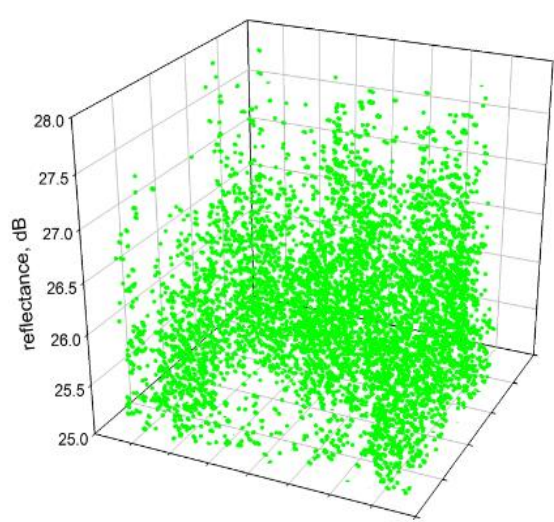

b) VH poliarization - 13/03/17

Fig. 9. Spatial reflectance distribution of wet snow in $\mathrm{dB}$

\section{CONCLUSION}

Using a differentiated approach and data from Sentinel-1 SAR and Sentinel-2 MSI sensors is extremely useful way to registering wet snow, because the weather limitations (e.g. cloud cover) can be minimized.

The SAR capabilities for wet snow monitoring are known to be extremely effective in terms of observation frequencies [8]. The wet snow mapping system has sufficient time and spatial resolution and could be valuable as the outbreak of snow during the melting season is of great interest and it must and can be registered via the C-band of the SAR $[7,9]$.

The results clearly show that wet snow and melting can be mapped using SAR data via vv- or hv-polarization. Based on spatial reflectance distributions, vertical polarization data can be accepted as much better suited for tracking the dynamics of wet snow. The SAR images in $\mathrm{dB}$ are most suitable for wet snow detection as accurate water and wet snow levels can be exactly determined. 


\section{REFERENCES}

1. Dozier, J. Spectral Signature of Alpine Snow Cover from the Landsat Thematic Mapper, Remote Sens. Environ. 28:9-22 (1989)

2. Freia A., M. Tedescob, et al. A review of global satellite-derived snow products, Advances in Space Research, 50 (2012), 1007-1029

3. Lawal D., Abdul-Nasir Matori, et al., Geographic Information System and Remote Sensing Applications in Flood Hazards Management: A Review, September 20, 2011. Research Journal of Applied Sciences, Engineering and Technology 3(9): 933-947, 2011ISSN: 2040-7467

4. Copernicus Scientific Data Hub, https://scihub.copernicus.eu/dhus/\#/home

5. Sentinel-2 MSI Introduction, https://sentinel.esa.int/web/sentinel/user-guides/ sentinel-2-msi

6. Level-1 Ground Range Detected, https:/earth.esa.int/web/sentinel/user-guides/sentinel-1 sar/resolutions/level-1-ground-range-detected
7. Nolin A., Recent advances in remote sensing of seasonal snow, Journal of Glaciology, Vol. 56, No.200, 2010

8. R. Nedkov, T. Spasova, D. Gotchev, A discriminative approach based on aerospace multispectral bands data in monitoring of snow cover and water, Ecological engineering and environment protection, Vol. 2 / 2016, p. 56-61, ISSN 1311-8668

9. Rott H., Prospects of microwave remote sensing for snow hydrology, Hydrologie, Applications of Space Technology (Proceedings of the Cocoa Beach Workshop, Florida, August 1985). IAHS Publ. No.160, 1986.

10. Недков Р, Д. Гочев, Т. Спасова, М. Захаринова. Анализ на наводнението на територията на град Скопие от месец август 2016 година на базата на спьтникови данни, Екологично инжинерство и опазване на околна среда, (2016) № 3, с.52-55, ISSN 1311-8668

\title{
МОНИТОРИНГ НА КРАТКОТРАЙНА СНЕЖНА ПОКРИВКА НА БАЗАТА НА ОПТИЧНИ И РАДАРНИ ДАННИ ОТ СПЪТНИЦИТЕ SENTINEL-1 и SENTINEL-2
}

\author{
Теменужка Спасова, Румен Недков
}

Резюме: Мониторингът чрез космически данни на мокра снежна покривка показва голямото значение на този твърд валеж, актуалността на данните от това събитие и пространственият обхват на наблюдавания обект.

Целта на това изследване е да се проследи използването на различни спътникови данни и подходи за проследяване на динамиката в развитието на мократа снежна покривка.

Предмет на изследването е краткотрайна снежна покривка и динамиката ѝ за териториата на София за дните 12 и 13 март 2017 година. Обектите са изследвани и картографирани по данни на Европейска Космическа Агенция от спьтниците Sentinel -1 и Sentinel -2.

Получени са резултати за количествени изменения на мокра снежна покривка и нейната динамика. Използваните данни са с висока времева и пространствена разделителна способност, което е наложително поради наличието на краткотрайно събитие.

Значението на този мониторинг е, че са получени дистанционни и достоверни данни, необходими при изчисляване на климатични модели и природни бедствия. Снегът е твърд валеж, чиято дебелина и продължителност зависят от много фактори.

Ключови думи: снежна покривка, радарни данни, оптичен диапазон, микровълнов диапазон, Sentinel-1 SAR, Sentinel-2 MSI.

Теменужка Спасова

Институт за космически изследвания и технологии - БАН

ул. Акад. Г. Бончев 1, София 1113

e-mail: tspasova@space.bas.bg

проф. д-р Румен Недков

Институт за космически изследвания и технологии - БАН

ул. акад. Г. Бончев 1, София 1113

e-mail: rnedkov@space.bas.bg
Temenuzhka Spasova

Space Research and Technology Institute-

Bulgarian Academy of Sciemces Acad. Georgi

Bonchev Str., B1. 1 Sofia 1113, Bulgaria

e-mail: tspasova@space.bas.bg

Prof. Roumen Nedkov, PhD

Space Research and Technology Institute-

Bulgarian Academy of Sciences

Acad. G.Bonchev Str., B1.1 Sofia 1113, Bulgaria

e-mail: rnedkov@space.bas.lbg 